\title{
On English Consonants
}

In teaching English the difficulties in pronunciation of consonants have been neglected, unfortunately, too, by many authors of English manuals. English consonants are not easy for foreigners to produce, and when pronounced wrongly they influence the pronunciation of the neighbouring vowel and thus make the whole word or phrase sound un-English.

What sort of difficulties is a Pole met with when he learns English? They are of two kinds, 1. phonetical and 2. phonological. The former fall into two groups:

a. being caused by a different place of articulation of Polish and

English consonants, e.g., Polish $\mathbf{n}$ is dental, English $\mathbf{n}$ is alveolar

b. being caused by a different way of articulation, e.g., Polish $\mathbf{d}$ and $\mathbf{t}$ are stops ${ }^{1}$, English $\mathbf{d}$ and $\mathbf{t}$ are plosive.

All these differences are shown in the table on page $128^{2}$.

The phonological difficulties are connected with different patterns of distribution of Polish and English consonantal phonemes. Single consonants do not cause trouble (apart, of course, from the difficulties mentioned above), except in final position. In Polish in this position there are only voiceless consonants, while in English the opposition voiced-voiceless is phonemically distinctive in final position.

The consonants $(\theta),(\beta)$ and $(\eta)$ occupy a separate place. The first two are easy sounds to produce, but they are difficult since they do not appear in the Polish phonological system and are being replaced by the nearest Polish equivalents (s) and (z), or (f) and (v) respectively. The sound ( $\eta$ ) exists in Polish but not in final position, and hence the pronunciation of ,coming" is either $(\mathrm{k} \wedge \mathrm{min})$ or $(\mathrm{k} \wedge \mathrm{mi \eta} \mathrm{k})$.

${ }^{1}$ The distinction plosive :| stop is based on the ammount of plosion.

2 See: W. Jassem A Spectrographic Study of Polish Speech Sounds, in In Honour of Daniel Jones. London 1964, pp. 334-349.

S. Szober Gramatyka języka polskiego, $6^{\text {th }}$ Ed., Warszawa 1963. PWN.

D. Jones Everyman's English Pronouncing Dictionary, $11^{\text {th }}$ Ed., London 1956. J. M. Dent and Sons Ltd. 


\begin{tabular}{|c|c|c|c|c|c|c|c|c|c|}
\hline & $\left|\begin{array}{c}\mathrm{Bi}- \\
\text { labial }\end{array}\right|$ & $\begin{array}{l}\text { Labio- } \\
\text { dental }\end{array}$ & Dental & Alveolar & $\begin{array}{l}\text { Post- } \\
\text {-alveol. }\end{array}$ & $\begin{array}{l}\text { Palato- } \\
\text {-alveol. }\end{array}$ & $\begin{array}{c}\text { Pala- } \\
\text { tal }\end{array}$ & Velar & Glottal \\
\hline Plosive & p b & & & $t d$ & & & & $\mathbf{k} \mathbf{g}$ & $?$ \\
\hline Stop & $\begin{array}{cc}p & b \\
p^{\prime} & b^{\prime}\end{array}$ & & $\begin{array}{cc}t & d \\
t^{\prime} & d^{\prime} \\
\end{array}$ & & & & J c & $\begin{array}{rr}k & g \\
k^{\prime} & g^{\prime}\end{array}$ & \\
\hline Affricate & & & dz ts & $\widehat{\mathrm{d}} \mathrm{z} \overline{\mathrm{t}} \int$ & & $t \int d z$ & $\mathrm{~d}_{z} \mathrm{t} \varphi$ & & \\
\hline Nasal & $\begin{array}{c}\mathbf{m} \\
\mathrm{m}^{\mathrm{m}} \mathrm{m}^{\prime}\end{array}$ & & $\mathrm{n}$ & $\mathbf{n}$ & & & $\mu$ & $\begin{array}{l}\eta \\
\eta\end{array}$ & \\
\hline Lateral & & & & $\begin{array}{c}1 \\
1 \\
1\end{array}$ & & & & & \\
\hline $\begin{array}{l}\text { Non- } \\
\text { lateral }\end{array}$ & & & & $\mathrm{r}$ & & & & & \\
\hline Fricative & & $\begin{array}{r}f \mathbf{v} \\
\mathrm{f} v \mathrm{f}^{\prime} \mathrm{v}^{\prime} \\
\end{array}$ & $\mid \begin{array}{ll}\theta & B \\
\text { s } & z \\
\end{array}$ & $\begin{array}{l}\text { s z } \\
z \int\end{array}$ & $\mathbf{r}$ & $\boldsymbol{z} \int$ & $\stackrel{c}{c}$ & $\begin{array}{c}x \\
x x^{\prime}\end{array}$ & h \\
\hline $\begin{array}{l}\text { Semi- } \\
\text { vowel }\end{array}$ & $\mathbf{w}$ & & & & & & $\begin{array}{l}\mathbf{j} \\
\mathbf{j}\end{array}$ & $\begin{array}{l}\mathbf{w} \\
\mathrm{w}\end{array}$ & \\
\hline
\end{tabular}

P Polish consonants

P English consonants

Consonant groups are more difficult, many of them do not exist in Polish. Here are the examples of English consonant clusters which are not met in Polish ${ }^{3}$ :

a. word-initial

(өr, $\theta \mathrm{W}$

pj, bj, өj, kj, sj, mj, nj

spj, stj, skj, smj)

b. intervocalic

$(\mathrm{se}, \mathrm{fe}$

ndz

er, el, өm, өj

$1 \mathrm{r}, 1 \mathrm{w}$

$\mathrm{kj}, \int \mathrm{j}$, zj, nj

skj, mfr, lfr, lpr, sem, nөm, nөj, ldr

3 See: M. Bargiełówna Grupy fonemów spótgloskowych wspótczesnej polszczyzny kulturalnej. Biuletyn Polskiego Towarzystwa Językoznawczego, X. Kraków 1950, pp. 1-25.

B. Trnka The Phonological Description of the Present Day Standard English. Studies in English (XXXVII - 5th Vol.), Prague 1935. 
$\left.\int \eta \mathrm{kt} \int, \eta \mathrm{kw}, 1 \mathrm{kr}, \eta \mathrm{gl}, 1 \mathrm{gr}, \eta \mathrm{gw}, \mathrm{nzd}, 1 \mathrm{st}, \mathrm{k} \int \mathrm{n}, \mathrm{nzj}\right)$

c. word-final

(mf, mz, nd, ne, nz, ndz, nz

$1 \mathrm{v}, \mathrm{lb}, 1 \mathrm{l}, \mathrm{dd}$

$\mathrm{jd}, \mathrm{jz}, \mathrm{jn}, \mathrm{jl}$

mps, nts, $\eta \mathrm{ks}, 1 \mathrm{ks}, 1 \mathrm{kt}$ )

The only way to overcome these difficulties leads through properly selected exercises. They will be different for Poles, Germans etc., because they depend on the phonetical and phonological systems of the mother tongue. Of these the teacher must be aware. He must have a minimum knowledge of Polish phonetics and phonology. It will enable him to predict the difficulties and concentrate on them.

These considerations allow us to draw the conclusion, that the manuals of foreign languages should be bilateral and based on contrastive studies of a native tongue and a foreign language.

The paper does not exhaust all the problems like e.g., consonant clusters in word-boundaries. They will have to be solved quickly if we want our students to speak good English. 